\title{
Biodiversity of Natuna as a Potential Ramsar Site of Wetlands with International Importance in Indonesia
}

\author{
Bony Irawan ${ }^{1 *}$, Risandi Dwirama Putra $^{2}$, Ani Suryanti ${ }^{3}$, Tengku Said Razai ${ }^{3}$, Imam Pangestyansah Putra ${ }^{3}$ \\ ${ }^{1}$ Department of Biology Education, Faculty of Education and Teacher Training, Universitas Maritim Raja Ali Haji. Tanjungpinang. \\ Indonesia. \\ ${ }^{2}$ Department of Shipping Engineering, Faculty of Engineering, Universitas Maritim Raja Ali Haji, Tanjungpinang, Indonesia. \\ ${ }^{3}$ Department of Marine Science, Faculty of Marine Science and Fisheries, Universitas Maritim Raja Ali Haji, Tanjungpinang, Indonesia
}

\begin{abstract}
Ramsar site designation is an acknowledgment of a wetland's importance. In this study, we conducted a biodiversity survey around Natuna to examine its eligibility as the next Ramsar site in Indonesia. This biodiversity survey was conducted through sampling for biological resources, using either transect, trapping, or visual observation. We surveyed 32 sampling stations for endangered and vulnerable fish, water birds, and wetland-dependent species. Samples were identified in meristic and morphometric form. We identified numerous endemic species and critically endangered, threatened, and vulnerable species. The most prominent native species are the endemic Presbytis natunae. Notable wood species are Eusideroxylon zwageri and Dipterocarpus sp., both critically endangered species. Sea grass species found in the coastal regions are Halodule pinifolia, Halophila ovalis, Enhalus acoroides, and Thalassia hemprichii. There are 52 species of fish found in the Natuna Sea, notably Bolbometopon muricatum, Oxymonacanthus longirostris, Plectropomus areolatus, and the endemic Cheilinus undulates. Numerous migrating birds and water birds are also found in the wetland and coastal region. The study concluded that Natuna fulfilled as a Ramsar site criteria based on its biodiversity characteristics and the support it provided to vulnerable species. We call for concentrated effort from the government for a successful nomination of Natuna as a Ramsar site..
\end{abstract}

Keywords: Natuna's biodiversity, Ramsar site, water birds, endemic species, endangered fish

\section{Introduction}

\subsection{Overview of Natuna's bio geographical characteristic}

Oil Natuna Island has unique bio geophysical characteristics. With the isolation of the vast expanse of seawater, the wetlands of Natuna Island tend to have unique biodiversity and high endemicity [1]. Due to its position, Natuna Islands also serves as an essential stepping stone for migrant species from the Malay Peninsula to the Indonesian archipelago [2]. Biogeographic characteristics of Natuna allowed for the formation of heavy vegetation and rich biodiversity in a terrestrial and aquatic ecosystems. In 2003 logged forest was known to cover $70 \%$ of the island [3], however, recent development shows that deforestation is occurring at an incremental pace.

Geomorphological characteristics of Natuna enable the formation of natural wetlands, such as tidal freshwater and brackish water, swamp forest, peat lands, open beaches, estuaries, mangrove forests, mudflats off the coast, and artificial wetlands such as reservoirs, peat lands, and pools or ponds that have not been mapped for its biodiversity. The wetland ecosystem in Natuna Island has unique biophysical characteristics. Isolated by a vast stretches of seawater, wetlands biodiversity in Natuna Island tend to have high endemicity, as well as high uniqueness of biological species. Natuna, in which this case, is represented by Bunguran Island, becomes a home for several endemic terrestrial and aquatic species [4]

Various environmental problems, including deforestation and land conversion, have decreased the population of endemic biota in Natuna Island [5]. Conservation effort has been limited and disjointed. It is a crucial time to explore options for the protection and conservation of Natuna's wetlands. One of the best strategies is to designate Natuna's wetlands as the Ramsar sites of wetlands with international importance.

\subsection{Ramsar site of wetlands with international importance}

Ramsar Convention or the Convention on Wetlands, is an intergovernmental treaty that provides the framework for national action and international cooperation for the conservation and the wise use of wetlands and their resources [6]. Article 2.1 of the Convention stipulated that 'Each Contracting Party shall designate suitable wetlands within its territory for inclusion in a List of Wetlands of International Importance, from now on referred to as "the List." The boundaries of each wetland shall be precisely described, and also delimited on a map. They may incorporate riparian and coastal zones adjacent to the wetlands, and

\footnotetext{
*Corresponding author: bony@umrah.ac.id
} 
islands or bodies of marine water deeper than six meters at low tide lying within the wetlands [7].

A designated Ramsar Site is managed with the purpose of maintaining its ecological character and retaining its essential functions and values for future generations [8]. Thus, giving a designated Ramsar Site a certain level of environmental protection and conservation status. Management of a designated Ramsar Site is guided by a set of procedures and strategic plans to ensure the site's preservation and wise usage [9]. Ramsar Site status will undoubtedly help the efforts to maintain Natuna's biodiversity for sustainable utilization of these resources.

In a recent development, Ramsar Site status transcended the conservation and environmental issues. Designation of trans boundary Ramsar Site, for example, affects bilateral diplomacy of neighboring countries [10]. Shared responsibility and close coordination required in managing the site help strengthen the relationship between involved parties [11] . In the Natuna case, including the island and its surrounding shallow waters in the Ramsar Site list will maintain Indonesia's sovereignty in the international forum amid the increasing tension in the South China Sea.

\subsection{Ramsar Site designation}

There are nine criteria that must be met for a wetland to be designated as Ramsar Site. These criteria are grouped into five prominent themes. Aspects prerequisite in the requirements are the uniqueness of the wetlands, the help it provides to the important, vulnerable, and endangered species, its support to the water birds and fishes, and its significant support to nonavian species. Initial assessment suggests that Natuna has the potential to be designated as the next Ramsar Site in Indonesia. However, a further biodiversity survey is required to confirm its eligibility according to the nomination criteria. This study was conducted to map the biodiversity of Natuna's wetland to assess its fulfillment to Ramsar Site criteria.

\section{Methods}

This biodiversity survey aimed to investigate Natuna's wetlands fulfillment to 9 criteria of a Ramsar Site. This biodiversity survey was conducted across Natuna Island and its surrounding waters and islets. We surveyed 19 locations for fish biodiversity sampling, 11 locations for terrestrial sampling, and 4 locations for sea grass sampling (Figure 1). Data collection was conducted in two stages, i.e. (1) Determination of the coordinates of wetlands area as biodiversity survey location in Natuna, (2) Biodiversity surveys at selected sampling station to map biological resources through sampling using either transects, traps, and photography to obtain clear visualization.

The samples obtained were further identified and morphometric both in the field and in the laboratory. Data collection were analyzed using GIS analysis, R statistical analysis, and descriptive analysis. Data are presented in order and being categorized to answer five prerequisite conditions of Ramsar Site characteristics.

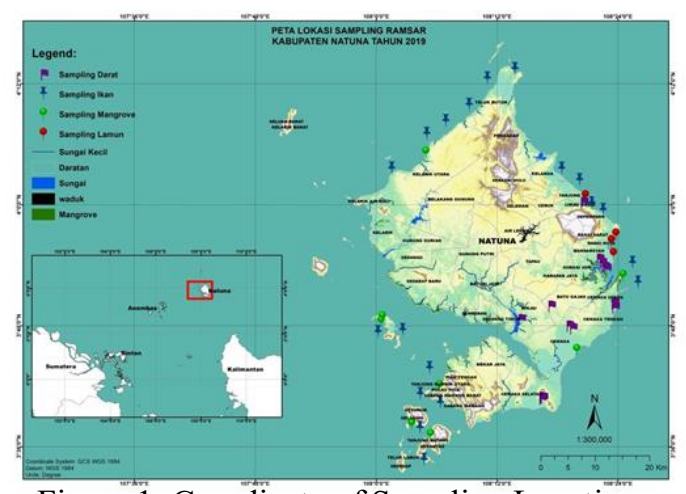

Figure 1. Coordinate of Sampling Locations

\section{Result and Discussion}

Natuna's topography is mostly lowland plains with several elevation points up to $1000 \mathrm{M}$ above the sea level. Soil structure generally consists of red and yellow podzolic soils consisting of rocks whose soil contains granite and alluvial material and organosol soil and grey humus. This allows for heavy vegetation, which provides support for high density and diversity of species [12]. the result of the study is organized and presented to answer five prerequisite conditions of Ramsar Site designation.

\subsection{Condition 1: The wetland contains a representative, rare, or unique example of a natural or near-natural wetland type}

From a biodiversity perspective, Natuna has several unique natural wetlands areas. The eastern part of Natuna particularly suits this description. These areas consist of wild swamps that serve as reservoirs and essential habitats to several endemic species. The swamp in Sekunyam forest is home to at least four endemic herpetofauna [13], such as bent-toed gecko Cyrtodactylus rosichonariefi and Cnemaspis mumpuniae. The swamp is a habitat for the endemic reptile while also serving as the water source for the terrestrial fauna. We found a colony of the endemic and endangered Presbytis natunae in the adjacent forest. The swamp is also acted as an important watershed from the surrounding landmass. These findings showed that Natuna has representative and unique wetlands which host rare and endemic species. Based on topology, elevation, and inundation, we visualized the map of Natuna wetlands in figure 2.

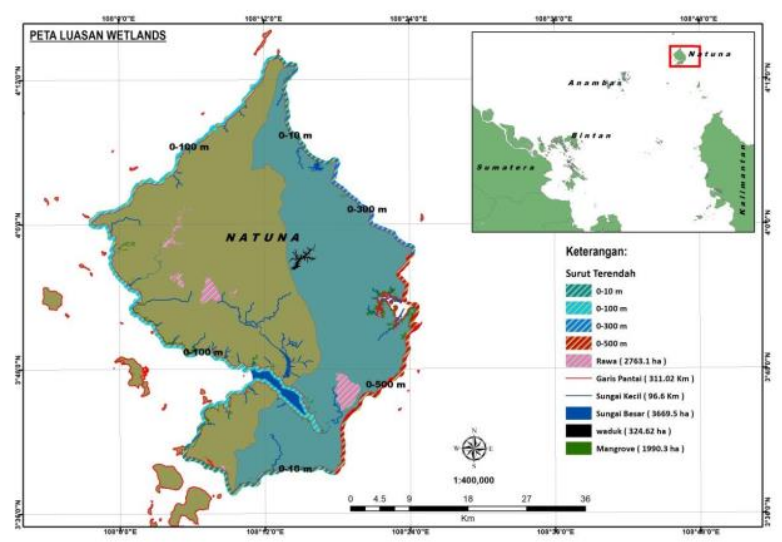

Figure 2. Map of Wetlands Distribution in Natuna 


\subsection{Condition 2: The site is of importance for biodiversity conservation}

This condition stipulated that a Ramsar Site must support vulnerable and endangered species. The study found several vulnerable species in Natuna's wetlands, such as: critically endangered wood species of Eusideroxylon zwageri and Dipterocarpus sp., endangered and vulnerable fish species of Bolbometopon muricatum and Cheilinus undulates, and the endemic and endangered mascot of Natuna, the Prebytis natunae. We documented 16 species from Natuna's wetlands that fulfill this condition, detailed in Table 1.

Table 1. Vulnerable and Endangered Species in Natuna

\begin{tabular}{|c|c|c|}
\hline No & Species Name & Status \\
\hline 1 & $\begin{array}{l}\text { Nepenthes } \\
\text { macrovulgaris }\end{array}$ & Vulnerable \\
\hline 2 & $\begin{array}{l}\text { Nepenthes } \\
\text { gymnamphora }\end{array}$ & Unique species \\
\hline 3 & $\begin{array}{l}\text { Stick bug of } \\
\text { Phasmatinae familiae }\end{array}$ & $\begin{array}{l}\begin{array}{l}\text { Potential of new } \\
\text { species }\end{array} \\
\end{array}$ \\
\hline 4 & $\begin{array}{l}\text { Toad of microhylidae } \\
\text { family }\end{array}$ & $\begin{array}{l}\text { High potential of } \\
\text { new species }\end{array}$ \\
\hline 5 & $\begin{array}{l}\text { Toad of microhylidae } \\
\text { family }\end{array}$ & $\begin{array}{l}\text { Possibility of new } \\
\text { species }\end{array}$ \\
\hline 6 & $\begin{array}{l}\text { Cytrodactylus } \\
\text { rosichonariefi }\end{array}$ & $\begin{array}{l}\text { Endemic reptile of } \\
\text { Natuna }\end{array}$ \\
\hline 7 & Presbytis Natunae & $\begin{array}{l}\text { Vulnerable, } \\
\text { endemic }\end{array}$ \\
\hline 8 & $\begin{array}{l}\text { Oxymonacanthus } \\
\text { longirostris }\end{array}$ & Vulnerable \\
\hline 9 & Shorea smithiana & $\begin{array}{l}\text { Critically } \\
\text { Endangered }\end{array}$ \\
\hline 10 & Shorea balange & $\begin{array}{l}\text { Critically } \\
\text { Endangered }\end{array}$ \\
\hline 11 & Eusideroxylon zwageri & Vulnerable \\
\hline 12 & $\begin{array}{ll}\text { Diplopods } & \text { of } \\
\text { glomeridae family }\end{array}$ & $\begin{array}{l}\text { Possibility of new } \\
\text { species }\end{array}$ \\
\hline 13 & Vitex pinnata & $\begin{array}{l}\text { Traditional } \\
\text { medicine }\end{array}$ \\
\hline 14 & Vitex pubescens & $\begin{array}{l}\text { Important } \\
\text { commodity }\end{array}$ \\
\hline 15 & $\begin{array}{l}\text { Bolbometopon } \\
\text { muricatum }\end{array}$ & Vulnerable species \\
\hline 16 & Cheilinus undulatus & $\begin{array}{l}\text { Endangered species, } \\
\text { important species }\end{array}$ \\
\hline
\end{tabular}

Natuna's wetlands provide support and serve as irreplaceable habitat to these vulnerable species. In the case of Presbytis natunae, the endemic leaf monkey has seen a steep population drop since 1990 [14]. Habitat loss is the main factor that causes the decline of Kekah's population. Despite being an arboreal primate, the Ramsar site's designation would help protecting Kekah's natural habitat [15].

\subsection{Condition 3: The wetland regularly support 20000 water birds and variation of water birds species.}

The third condition for a wetland to be considered as a Ramsar Site is that it must regularly supports 20000 water birds while also periodically supporting $1 \%$ of the individuals in a population of one species or subspecies of water bird [16]. We conducted the survey for water birds in Natuna and documented 25 species with varying abundance.

Table 2. Bird Species Found in Natuna

\begin{tabular}{|c|l|c|}
\hline No & \multicolumn{1}{|c|}{ Species Name } & Count \\
\hline 1 & Artamus leucorhyachus & 28 \\
\hline 2 & Calidris ferruginea & 216 \\
\hline 3 & Bubulcus ibis & 64 \\
\hline 4 & Lear aifinis & 4 \\
\hline 5 & Todirhampus chloris & 15 \\
\hline 6 & Nectarinia calcostetha & 26 \\
\hline 7 & Phylloscopus coronatus & 8 \\
\hline 8 & Haliaeetus leucogaster & 11 \\
\hline 9 & Spilornis cheela & 3 \\
\hline 10 & Anthracoceros albirostris & 2 \\
\hline 11 & Amaurornis phoenicurus & 70 \\
\hline 12 & Dicaeum trochileum & 2 \\
\hline 13 & Nectarinia jugular & 8 \\
\hline 14 & Hemiprocne comata & 2 \\
\hline 15 & Lacedo pulchella & 2 \\
\hline 16 & Otus spilocephalus vandewateri & 5 \\
\hline 17 & Passer Montanus & 104 \\
\hline 18 & Philomachus Pugnax & 32 \\
\hline 19 & Egretta sacta & 53 \\
\hline 20 & Treron vernans & 2 \\
\hline 21 & Apus affinis & 51 \\
\hline 22 & Ducula aenea & 12 \\
\hline 23 & Dicrutus sumatranus & 4 \\
\hline 24 & Hirundo tahitica & 560 \\
\hline 25 & Sterna sumatrana & \\
\hline & & \\
\hline
\end{tabular}

Regarding the water birds criteria, data from this study is limited, especially in the number and biodiversity of migratory birds. We suggest a year-long survey after identifying potential spots for migratory birds landing spots [17]. From this limited data, we believe that the actual number of water birds species in Natuna will exceed the minimum required numbers.

\subsection{Condition 4: The wetland's support of indigenous} fish species and its support of migratory fish species

This condition stipulate that the wetland supports a significant proportion of indigenous fish subspecies, species or families, life-history stages, species interactions and, or populations that are representative of the benefits of wetland and, or values and thereby contributes to global biological diversity. It must also serve as an essential food source for fishes, spawning ground, nursery and, or migration path for fish, either within the wetland or elsewhere. The fish's biodiversity survey was conducted in 19 locations in shallow waters around Natuna's main island and the south western 
islets. The study documented 48 fish species, detailed in Table 3.

Table 3. Fish Species Documented in Natuna

\begin{tabular}{|c|c|c|c|}
\hline No & Species name & No & Species name \\
\hline 1 & $\begin{array}{l}\text { Scarus } \\
\text { hypselopterus }\end{array}$ & 25 & $\begin{array}{l}\text { Diagramma } \\
\text { pictum }\end{array}$ \\
\hline 2 & $\begin{array}{l}\text { Bolbometopon } \\
\text { muricatum }\end{array}$ & 26 & $\begin{array}{l}\text { Lethrinus atkin } \\
\text { Putrai }\end{array}$ \\
\hline 3 & $\begin{array}{l}\text { Cheilinus } \\
\text { undulates }\end{array}$ & 27 & Lethrinus harak \\
\hline 4 & $\begin{array}{l}\text { Oxymonacanthu } \\
\text { s longirostris }\end{array}$ & 28 & $\begin{array}{l}\text { Lethrinus } \\
\text { erythropterus }\end{array}$ \\
\hline 5 & Scarus forsteni & 29 & $\begin{array}{l}\text { Lutjanus } \\
\text { argentimaculat } \\
\text { us }\end{array}$ \\
\hline 6 & Scarus frenatus & 30 & $\begin{array}{l}\text { Lutjanus } \\
\text { carponotatus }\end{array}$ \\
\hline 7 & $\begin{array}{l}\text { Chlorurus } \\
\text { spilurus }\end{array}$ & 31 & $\begin{array}{l}\text { Lutjanus } \\
\text { quinquelineatus }\end{array}$ \\
\hline 8 & Scarus ghobban & 32 & $\begin{array}{l}\text { Lutjanus } \\
\text { biguttatus }\end{array}$ \\
\hline 9 & Scarus spinus & 33 & $\begin{array}{l}\text { Symphorichthys } \\
\text { spilurus }\end{array}$ \\
\hline 10 & $\begin{array}{l}\text { Chlorurus } \\
\text { bleekeri }\end{array}$ & 34 & $\begin{array}{l}\text { Lutjanus } \\
\text { decussatus }\end{array}$ \\
\hline 11 & $\begin{array}{l}\text { Scarus } \\
\text { dimidiatus }\end{array}$ & 35 & $\begin{array}{l}\text { Lutjanus } \\
\text { russellii }\end{array}$ \\
\hline 12 & $\begin{array}{l}\text { Chlorurus } \\
\text { capistratoides }\end{array}$ & 36 & $\begin{array}{l}\text { Lutjanus } \\
\text { fulviflamma }\end{array}$ \\
\hline 13 & $\begin{array}{l}\text { Cetoscarus } \\
\text { ocellatus }\end{array}$ & 37 & $\begin{array}{l}\text { Diploprion } \\
\text { bifasciatum }\end{array}$ \\
\hline 14 & Scarus quoyi & 38 & $\begin{array}{l}\text { Atelomycterus } \\
\text { marmoratus }\end{array}$ \\
\hline 15 & $\begin{array}{l}\text { Chlorurus } \\
\text { microrhinos }\end{array}$ & 39 & $\begin{array}{l}\text { Chiloscyllium } \\
\text { punctatum }\end{array}$ \\
\hline 16 & $\begin{array}{l}\text { Ctenochaetus } \\
\text { striatus }\end{array}$ & 40 & Taeniura lymma \\
\hline 17 & Naso lituratus & 41 & $\begin{array}{l}\text { Taeniura } \\
\text { meyeni }\end{array}$ \\
\hline 18 & $\begin{array}{l}\text { Zebrasoma } \\
\text { velifer }\end{array}$ & 42 & $\begin{array}{l}\text { Plectropomus } \\
\text { maculatus }\end{array}$ \\
\hline 19 & $\begin{array}{l}\text { Siganus } \\
\text { corallinus }\end{array}$ & 43 & $\begin{array}{l}\text { Plectropomus } \\
\text { laevis }\end{array}$ \\
\hline 20 & $\begin{array}{l}\text { Siganus } \\
\text { vulpinus }\end{array}$ & 44 & $\begin{array}{l}\text { Cephalopholis } \\
\text { boenak }\end{array}$ \\
\hline 21 & $\begin{array}{l}\text { Plectorhinchus } \\
\text { lesPutraii }\end{array}$ & 45 & Caesio teres \\
\hline 22 & $\begin{array}{l}\text { Plectorhinchus } \\
\text { polytaenia }\end{array}$ & 46 & $\begin{array}{l}\text { Chaetodon } \\
\text { trifascialis }\end{array}$ \\
\hline 23 & $\begin{array}{l}\text { Plectorhinchus } \\
\text { chaetodonoides }\end{array}$ & 47 & $\begin{array}{l}\text { Chlorurus } \\
\text { bowersi }\end{array}$ \\
\hline 24 & $\begin{array}{l}\text { Plectorhinchus } \\
\text { lineatus }\end{array}$ & 48 & $\begin{array}{l}\text { Carcharhinus } \\
\text { limbatus }\end{array}$ \\
\hline
\end{tabular}

Among the 48 species found in Natuna which listed in Table 3, there is one endemic species and several vulnerable or endangered fish species. In the case of Cheilinus undulatus, the napoleon fish is an endemic species which currently in high demand in the international market. Napoleon fish is an endangered species and due to the high demand, it saw an extensive catching which worsened its situation [18] Napoleon fish is one of the largest fish associated with coral reefs [19]. It can be found roaming the region of a fringing reef in the lagoon area to the area with steep coral reefs in Natuna waters, as seen in Figure 3. Napoleon fish is just one of many vulnerable species that depend on the wetlands of Natuna.

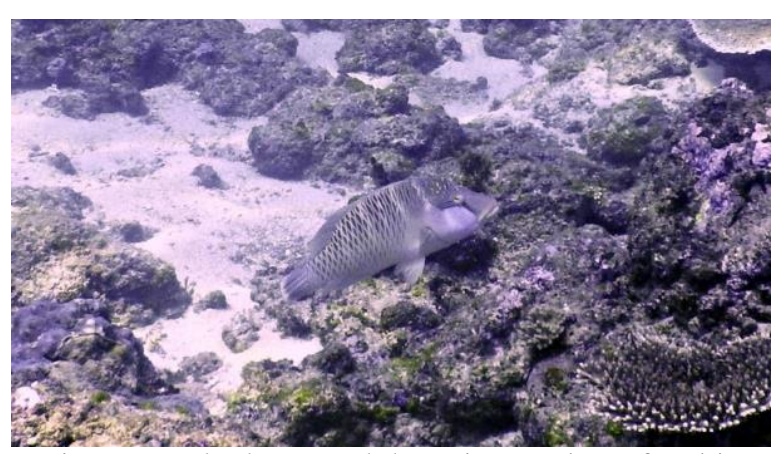

Figure 3. Cheilinus undulatus in Coral Reef Habitat. Photo by: Risandi Dwirama Putra

Another vulnerable species is Oxymonacanthus longirostris, a beautiful reef roamer highly valued as ornamental fish. It is characterized with orange spots throughout its body and fore-gaping snout for catching coral polyps [20,21]. Oxymonacanthus longirostris is also in high demand on the international market and is currently categorized as vulnerable species. It is found in Natuna's coral reefs by a non-migratory range in the depth of 0.5 meters to 35 meters.

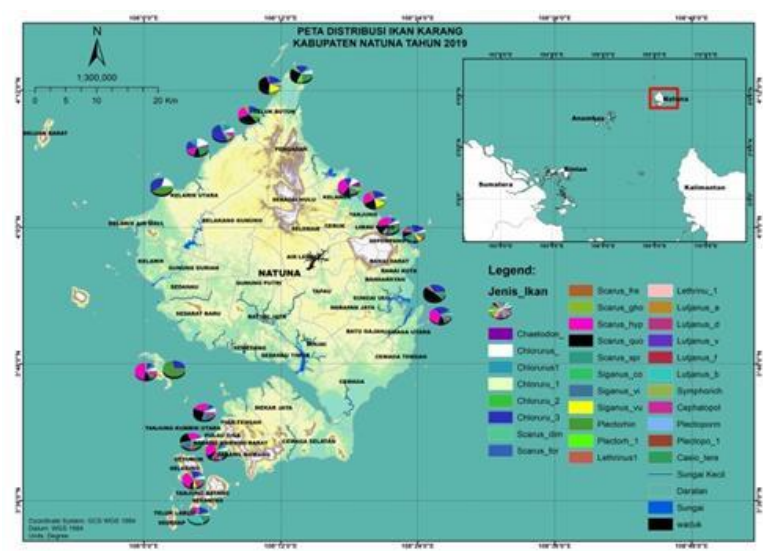

Figure 4. Biodiversity Distribution of Fishes in Natuna

3.5 Condition 5: The wetland regularly supports $1 \%$ of the individuals in a population of one species or subspecies of wetland-dependent non-avian animal species

Based on the biodiversity data recorded, the number of non-avian wetland species is fulfilling the mentioned criteria. We documented hundreds of nonavian wetlands-dependent species in several sampling stations in Natuna. Sea grass is an amazing group to illustrate how Natuna's wetland fulfilled the last criteria of a Ramsar Site. There are four species documented in this study, which are Enhalus acoroides, Thalassia hemprichii, Halodule pinifolia, and Halophila ovalis. The composition of sea grass species in the waters of 
Natuna's Bunguran Island is about $33 \%$ of the total species found in Indonesia (12 species) [22].

The highest composition of sea grass found is Halophila ovalis, reaching $64.73 \%$. In comparison, Halodule pinifolia has a composition of $34.18 \%$, the Enhalus acroides species composition is $0.69 \%$, and Thalassia hemprichii is the lowest composition which at only $0.4 \%$. Halophila ovalis species composition is the highest at each sampling location compared to other species. This pattern is supported by the substrate condition of rubble sand mixture being alive in the sea grass habitat of this species. In general, sea grass species with a significant morphological conditions such as Enhalus acoroides and a kind of Thalassia hemprichii have a larger composition because of the ability to adapt and develop a good root structure [23]. But in Natuna, Halophila ovalis is a dominant species of this region, showcasing the uniqueness of sea grass.

Coastal geomorphology is also unique, the area covered by sea grass's adjacent to the coral reef area leading to the intermingling of species, that some organisms generally found in coral reefs area are also found in sea grass. Comparing to the other, sea grass's domination and its distribution are unique. This uniqueness is contributed by the position of Natuna and its substrate characteristics. The substrate in the neritic zone of Natuna is a coarse sand with the depth of 20$30 \mathrm{~cm}$. Under the thin sands is bedrock, which prohibited larger and deep rooted sea grass from dominating [24].

\section{Conclusion}

Based on the results, we conclude that in the perspective of biodiversity criteria, Natuna Island is a suitable candidate for the next Ramsar Site in Indonesia. The study documented six endemic species, six vulnerable species, four endangered species, 25 bird species, 48 fish species, and four sea grass species. Wetland plains on the eastern side of Natuna Island is the most potential to be designated as Ramsar site based on its biodiversity, wetlands characteristics, and its importance. We suggest further studies, especially an all-year water birds survey, to confirm the number of migratory water birds on the island. For Natuna's candidacy as Ramsar site, we call for coordinated efforts from all affiliated institutions to support the designation of Natuna as a Ramsar Site of the wetland of international importance.

\section{References}

1. C. Gascon and O. de S. Pereira, Revista Brasileira de Zoologia 10, 179 (1993).

2. L. L. Grismer, Journal of Herpetology 39, 424 (2005).

3. M. Lammertink, V. Nijman, and U. Setiorini, Oryx 37, 472 (2003).

4. C. M. Yang and A. D. Tran, The Raffles Bulletin of Zoology 55 (2004).

5. D. Girmansyah, Kew Bulletin 68, 179 (2013).

6. T. J. Davis, Agris.Fao.Org (1994).

7. I. M. Hasmadi, H. Z. Pakhriazad, and K. Norlida, Sains Malaysiana (2011).
8. S. An, H. Li, and B. Guan, 36, 335 (2007).

9. E. Firouz, Biological Conservation 76 (1971).

10. R. Ramsar, Burlington: Institute for Environmental Diplomacy \& Security (2012).

11. T. Greiber, M. Smith, and B. Ger, Managing Water across Boundaries (2008).

12. M. de Bruyn, B. Stelbrink, R. J. Morley, R. Hall, G. R. Carvalho, C. H. Cannon, G. van den Bergh, E. Meijaard, I. Metcalfe, L. Boitani, L. Maiorano, R. Shoup, and T. von Rintelen, Systematic Biology 63, 879 (2014).

13. A. Riyanto, L. L. Grismer, and P. L. Wood, Zootaxa 3964, 114 (2015).

14. E. Meijaard, D. Sheil, R. Nasi, D. Augeri, B. Rosenbaum, D. Iskandar, T. Setyawati, M. Lammertink, I. Rachmatika, and A. Wong, Life After Logging: Reconciling Wildlife Conservation and Production Forestry in Indonesian Borneo (2005).

15. V. Stojanović, L. Lazić, and J. Dunjić, Geographica Pannonica 22, 201 (2018).

16. B. D. Hansen, J. K. Szabo, R. A. Fuller, R. S. Clemens, D. I. Rogers, and D. A. Milton, Biological Conservation 260, 109189 (2021).

17. S. Bauer and B. J. Hoye, Science 344, (2014).

18. M. Dorenbosch, M. G. G. Grol, I. Nagelkerken, and G. van der Velde, Biological Conservation 129, 277 (2006)

19. R. D. Sluka, Humphead Wrasse (Cheilinus Undulatus) and Size Structure among Coral Reef Habitats in Maldives (Atoll research bulletin, 2005).

20. G. W. Barlow, Environmental Biology of Fishes 1987 20:3 20, 183 (1987).

21. T. Kokita and A. Nakazono, Ichthyological Research 46, 297 (1997).

22. N. Asriani, R. Ambo-Rappe, M. Lanuru, and S. L. Williams, Botanica Marina 61, 205 (2018).

23. M. Kawaroe, A. H. Nugraha, J. Juraij, and I. A. Tasabaramo, Biodiversitas Journal of Biological Diversity 17, 585 (2016).

24. R. K. F. Unsworth, R. Ambo-Rappe, B. L. Jones, Y. A. la Nafie, A. Irawan, U. E. Hernawan, A. M. Moore, and L. C. Cullen-Unsworth, Science of The Total Environment 634, 279 (2018). 